\title{
Incidence of rapid increase of plasma sodium during liver transplantation and ITS effect on outcome
}

\author{
NT Yoh, T Lai, G Wagener ${ }^{*}$ \\ From ESICM LIVES 2015 \\ Berlin, Germany. 3-7 October 2015
}

\begin{abstract}
Introduction
Rapid correction of hyponatremia can cause pontine myelinolysis and should be corrected by less than $10 \mathrm{mM} / \mathrm{L}$ within 24 hours. Hepatic cirrhosis is often associated with hyponatremia due to fluid retention and ascites. During liver transplantation, sodium may increase because of fluid administration and blood transfusions. Little is known regarding the frequency of rapid sodium increases during liver transplantation and whether such rapid corrections carry detrimental effects.
\end{abstract}

\section{Objectives}

To determine the incidence of rapid plasma sodium correction in liver transplants and their effect on outcome.

\section{Methods}

We retrospectively analyzed data from 607 liver transplants at a single institution. Rapid correction of sodium was defined as an increase of serum sodium by more than $10 \mathrm{mM} / \mathrm{L}$ within 24 hours after the start of liver transplantation when compared to preoperative sodium levels. Primary endpoint was 90-day mortality or graft failure requiring re-transplantation.

\section{Results}

Plasma sodium concentrations increased by more than $10 \mathrm{mM} / \mathrm{L}$ within 24 hours after liver transplantation in 39 of 607 patients (6.4\%). These patients had lower preoperative sodium levels $(129+/-5.2$ vs. $134+/-4.5 \mathrm{mM} / \mathrm{L}$, $\mathrm{p}<0.001)$ and higher MELD scores $(33.9+/-7.1$ vs. 20.4 vs. $10.2, \mathrm{p}<0.001)$. Sodium levels increased by 14.6 $+/$ - 3.9; range $11-28 \mathrm{mM} / \mathrm{L}$ in the rapid increase group (figure 1). 39 patients died or required re-transplantation within 90 days. Even though the group with rapid $\mathrm{Na}$ increases had higher preoperative MELD scores there was no significant difference with regard to 90-day mortality/ graft failure compared to patients with rapid increase and no rapid increase of sodium $(4 / 39-10.3 \%$ vs. $35 / 568$ or $6.2 \%, \mathrm{~ns})$. One patient with a rapid perioperative increase of sodium (from $131 \mathrm{mM} / \mathrm{L}$ preoperative to $151 \mathrm{mM} / \mathrm{L}$ immediately after transplantation (figure 2)) had cerebral edema and severe cortical necrosis postoperatively and died 46 days after transplantation. However, this patient had acute decompensated hepatitis and severe mental status changes prior to transplantation.

\section{Conclusions}

Perioperative rapid increases of sodium above what is recommended for correction of hyponatremia occurred in over $6 \%$ of all cases with only one case of severe neurological complication that was not consistent with pontine myelinolysis. Perioperative increases of plasma may be less dangerous than previously thought if it is not associated

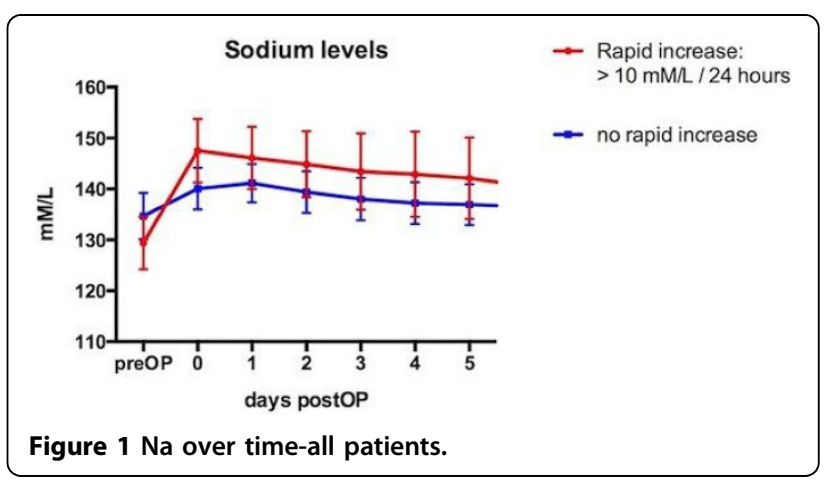




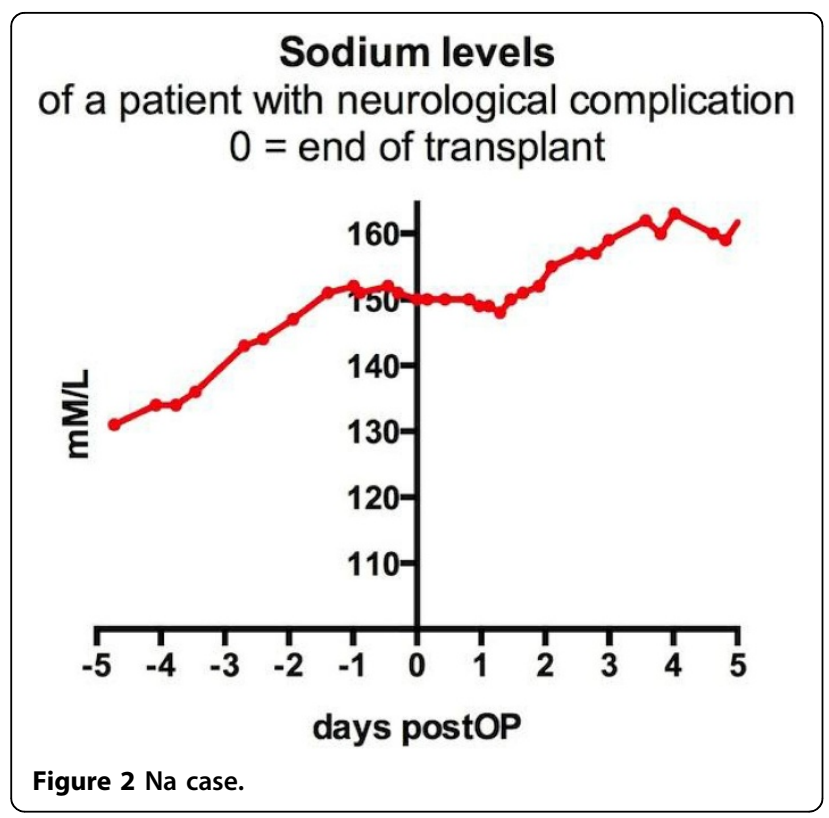

with abrupt changes of plasma osmolality. The neurological complication (cerebral edema, not pontine myelinolysis) of the patient described above are more likely attributable to her preoperative acute liver failure than rapid increase of sodium concentrations.

Published: 1 October 2015

\section{References}

1. New England Journal of Medicine 2000, 342(21):1581-1589.

2. Am J Med 2013, 126(10 Suppl 1):S1-42, Oct.

doi:10.1186/2197-425X-3-S1-A695

Cite this article as: Yoh et al:: Incidence of rapid increase of plasma

sodium during liver transplantation and ITS effect on outcome. Intensive

Care Medicine Experimental 2015 3(Suppl 1):A695.

\section{Submit your manuscript to a SpringerOpen ${ }^{\mathcal{O}}$ journal and benefit from:}

- Convenient online submission

- Rigorous peer review

- Immediate publication on acceptance

- Open access: articles freely available online

- High visibility within the field

- Retaining the copyright to your article

Submit your next manuscript at $>$ springeropen.com 